\title{
MENINGKATKAN PRESTASI BELAJAR MELALUI PENGGUNAAN TEKNIK JIGSAW
}

\author{
Meyke Machrita Mamahit \\ Institut Agama Kristen Negeri Manado \\ meyke.mamahit@iakn-manado.ac.id \\ Diterima 29 September 2019 \\ Disetujui 30 Oktober 2019
}

\begin{abstract}
This study aims (1) to improve student achievement in class A semester VI Christian Religious Education Study Program Manado State Christian Religion Institute through cooperative learning with jigsaw techniques, (2) to increase interest and motivation to learn students in class A semester VI Education Study Program Christian Religion Institute of Manado State Christian Religion through cooperative learning with jigsaw techniques. This research is classroom action research. Total population of 145 people and a sample of 14 people. The research data were obtained from test scores on pre-cycle, cycle 1, cycle 2 and questionnaire. The results showed that cooperative learning with jigsaw techniques can significantly improve achievement, interest and motivation of students in class A semester VI of the IAKN Manado Christian Religious Education Study Program. The percentage of the number of students who obtained a minimum passing grade achievement increased from $60 \%$ in the pre-cycle to $80 \%$ in cycle 1, and to $90 \%$ in cycle II. Students' interest and learning motivation increases, from $70 \%$ in cycle 1 to $90 \%$ in cycle 2.
\end{abstract}

Keywords: Learning achievement, Jigsaw Technique

\section{ABSTRAK}

Penelitianini bertujuan (1) untuk meningkatkan prestasi belajar peserta didik kelas A semester VI Program Studi Pendidikan Agama Kristen Institut Agama Kristen Negeri Manado melalui pembelajaran kooperatif dengan teknik jigsaw, (2) untuk meningkatkan minat dan motivasi belajar peserta didik kelas A semester VI Program Studi Pendidikan Agama Kristen InstitutAgama Kristen Negeri Manado melalui pembelajaran kooperatif dengan teknik jigsaw. Penelitian ini adalah penelitian tindakan kelas. Jumlah populasi 145 orang dan sampel 14 orang. Data penelitian diperoleh dari nilai tes pada prasiklus, siklus 1, siklus 2 dan kuesioner. Hasil penelitian menunjukkan pembelajaran kooperatif dengan teknik jigsaw dapat meningkatkan prestasi, minat dan motivasi belajar peserta didik kelas A semester VI Program Studi Pendidikan Agama Kristen IAKN Manado secara signifikan. Prosentase jumlah peserta didik yang memperoleh nilai capaian kelulusan minimum meningkat dari $60 \%$ di prasiklus menjadi $80 \%$ di siklus 1 , dan menjadi $90 \%$ di siklus II. Minat dan motivasi belajar peserta didik meningkat, dari $70 \%$ pada siklus 1 menjadi $90 \%$ pada siklus 2 .

Keywords: Prestasi belajar, Teknik Jigsaw

\section{PENDAHULUAN}

$$
\text { Pendidikan merupakan suatu }
$$

lembaga yang memegang peranan penting dalam menciptakan sumber daya manusia yang bermutu. Bangsa yang ingin maju adalah bangsa yang peduli akan kemajuan pendidikan. Karena masyarakat yang cerdas dan berkualitas hanya dapat diperoleh melalui pendidikan yang bermutu.

Sekolah dan perguruan tinggi sebagai suatu lembaga pendidikan formal sangat berperan dalam menghasilkan sumberdaya manusia bermutu yang sangat diharapkan oleh suatu bangsa. Itulah sebabnya berbagai upaya pengembangan maupun pembaharuan telah dilakukan oleh 
pemerintah dan berbagai pihak swasta untuk meningkatkan mutu pendidikan agar dapat bersaing di dunia Internasional.

Menurut Tilaar (1990:187), bukan saja bagi para professional, juga bagi masyarakat luaspun terdapat suatu gerakan yang menginginkan adanya perubahan sekarang juga dalam hal usaha peningkatan mutu atau kualitas pendidikan. ${ }^{1}$

\section{Soedijarto} mengemukakan bahwa rendahnya mutu atau kualitas pendidikan disebabkan oleh karena pemberian peranan yang kurang proporsional terhadap sekolah, kurang memadainya perencanaan, pelaksanaan, dan pengelolaan sistem kurikulum, dan penggunaan prestasi hasil belajar secara kognitif sebagai satu-satunya indikator keberhasilan pendidikan, juga disebabkan karena sistem evaluasi tidak secara berencana didudukkan sebagai alat pendidikan dan bagian terpadu dari sistem kurikulum. $^{2}$

Dengan melihat keadaan mutu pendidikan yang rendah, maka telah diupayakan usaha-usaha dalam meningkatkan mutu pendidikan, seperti: penyempurnaan kurikulum, perbaikan sarana dan prasarana, kecukupan dana operasional sekolah, manajemen sekolah, dan lain-lain.Akan tetapi upaya-upaya yang

${ }^{1}$ Tilaar, Paradigma Baru Pendidikan Nasional, Jakarta: Rineka Cipta, 1990, p. 87. telah dilakukan tersebut belum cukup memberikan kemajuan yang berarti bagi sekolah dan perguruan tinggi dalam mencapai sekolah dan perguruan tinggi yang berkualitas serta berdaya saing tinggi tanpa adanya kesadaran dan usahadari tenaga pendidik untuk membenahi diri sebagai pelaku utama dan merupakan ujung tombak pelaksanaan proses pembelajaran. Rendahnya mutu pendidikan dibuktikan dengan masih adanya hasil belajar peserta didik yang belum mencapai Kriteria Kelulusan Minimal yang telah ditentukan.

Dengan demikian diharapkan agar tenaga pendidik sebagai pelaku utama pendidikan yang menjadi penentu keberhasilan pembelajaran dikelas hendaknya memiliki pengetahuan, kompetensi dan ketrampilan profesional yang memadai.Itulah sebabnya guru hendaknya selalu melakukan pengembangan diri dan beradaptasi dengan kemajuan jaman khusunya dibidang pendidikan.

$$
\text { Proses pembelajaran yang }
$$
berlangsung di kelas ditandai dengan adanya perubahan yang terjadi pada diri peserta didik yang belajar. Perubahan yang terjadi sebagai hasil dari proses pembelajaran ditunjukkan dalam berbagai bentuk seperti perubahan pada aspek

\footnotetext{
${ }^{2}$ Soedijarto, Media Pembelajaran, Modul PLPG, Surakarta: 2008, p. 56.
} 
pengetahuan, ketrampilan dan sikap/tingkahlaku. Perubahan tingkah laku sebagai hasil dari proses belajar tersebut, merupakan serangkaian pengalaman yang diperoleh si pembelajar dalam berinteraksi dengan lingkungan dimana ia berada, serta berlangsung relatif agak lama.

Menurut Slameto (1988:2) belajar adalah proses yang dilakukan oleh individu untuk memperoleh suatu perubahan tingkah laku yang baru secara keseluruhan sebagai hasil dari pengalaman individu itu sendiri dalam berinteraksi dengan lingkungannya. ${ }^{3}$ Senada dengan pendapat tersebut, Nana Sudjana (2010:5) mengemukakan bahwa belajar adalah suatu proses yang ditandai dengan adanya perubahan pada diri seseorang. Perubahan tersebut dapat ditunjukan dalam berbagai bentuk seperti perubahan pengetahuan, pemahaman, sikap, dan tingkah laku, keterampilan, kecakapan, kebiasaan, serta perubahan aspek-aspek lain yang ada pada individu yang belajar. ${ }^{4}$

Oemar Hamalik dalam Siregar (1989:16), berpendapat bahwa "Belajar adalah bentuk pertumbuhan dalam diri seseorang, yang di dalam tingkah laku (gerak, berbicara, mengemukakan

\footnotetext{
${ }^{3}$ Slameto, Belajar dan Faktor-Faktor yang Mempengaruh Proses Belajar, Jakarta: PT Rineka Cipta, 2018, p. 5.

${ }^{4}$ Nana, Sudjana, Cara belajar Siswa Aktif dalam Proses Belajar Megajar, Bandung: Sinar BaruAlgensindo, 2010,p. 5.
}

pendapat, memberikan jawaban pada suatu masalah, memberikan pengaruh dan lainlain) yang merupakan berkat dari pengalaman dan latihan yang berulangulang". 5 Selanjutnya Dharma Kesuma dkk (2012:21) berpendapat bahwa belajar adalah suatu pengalaman yang mendahului perubahan perilaku seseorang. ${ }^{6}$

Dari pengertian belajar yang dikemukakan diatas dapat disimpulkan bahwa belajar adalah suatu aktifitas yang sengaja dilakukan oleh individu agar dapat terjadi perubahan tingkah laku di dalam diri individu tersebut, sebagai hasil pengalaman sendiri dalam berinteraksi dengan individu lainnya serta lingkungan sekitar. Belajar tidak dibatasi oleh ruang dan waktu serta dilakukan secara terus-menerus.

Prestasi adalah sesuatu yang dapat dicapai yang dinampakkan dalam pengetahuan, sikap, dan ketrampilan/keahlian. Prestasi tidak akan pernah dihasilkan selama seseorang tidak melakukan suatu kegiatan. Untuk mendapatkan prestasi dibutuhkan keuletan, ketelitian dan kegigihan kerja. Menurut Hamdani (2011:137) prestasi yaitu hasil dari suatu kegiatan yang telah dikerjakan, diciptakan baik secara individual maupun

\footnotetext{
${ }^{5}$ Oemar Hamalik, Proses Belajar Mengajar, Jakarta: Bumi Aksara, 2005, p. 16.

${ }^{6}$ Dharma Kesumadkk., Pendidikan Karakter Kajian Teori dan Praktik di Sekolah, Bandung: PT Remaja Rosdakarya, 2012, p. 21.
} 
kelompok. ${ }^{7}$ Sedangkan menurut Syaiful

Bahri Djamarah (2012:21) prestasi yaitu hasil dari suatu kegiatan yang telah dikerjakan, diciptakan, yang menyenangkan hati yang diperoleh dengan jalan keuletan kerja, baik secara individual maupun kelompok dalam bidang kegiatan tertentu. $^{8}$

Berdasarkan uraian di atas, dapat disimpulkan bahwa prestasi adalah hasil dari melakukan, menciptakan suatu kegiatan tertentu dengan ulet dan menyenangkan hati,baik yang dilakukan secara individu maupun kelompok. Sardiman (2011:46) mengemukakan bahwa prestasi belajar merupakan kemampuan nyata yang merupakan hasil interaksi antara berbagai faktor yang mempengaruhi baik dari dalam maupun dari luar diri individu dalam belajar. ${ }^{9}$ Sedangkan Hamdani (2011:138) berpendapat bahwa prestasi belajar yaitu hasil yang diperoleh berupa kesan-kesan yang mengakibatkan perubahan dalam diri individu sebagai hasil dari sebuah aktivitas. ${ }^{10}$ Sejalan dengan pendapat tersebut, Syaiful Bahri Djamarah (2012:23) prestasi belajar yaitu hasil yang diperoleh berupa kesan-kesan yang mengakibatkan perubahan dalam diri

${ }^{7}$ Hamdani, Strategi Belajar Mengajar, Bandung: Pustaka Setia, 2011, p. 137.

${ }^{8}$ Syaiful Bahri Djamarah, Prestasi Belajar Dan Kompetensi Guru. Surabaya: Usaha Nasional, 2012, p.21. individu sebagai hasil dari aktivitas dalam belajar. ${ }^{11}$

Berdasarkan uraian di atas dapat disimpulkan bahwa prestasi belajar adalah hasil yang diperoleh dari suatu aktivitas belajar yang mengakibatkan perubahan perilaku. Prestasi belajar ditunjukkan dengan nilai tes atau angka yang diberikan guru sebagai hasil dari usaha meningkatkan prestasi belajarnya pula. Pelaksanaan kegiatan pembelajaran di kelas yang diharapkan adalah proses pembelajaran yang berkualitas yang dapat meningkatkan prestasi belajar peserta didik. Proses pembelajaran hendaknya mengacu pada bagaimana siswa belajar, bukan hanya apa yang dipelajari siswa. Pelaksanaan proses pembelajaran yang berkualitas adalah proses pembelajaran yang berlangsung secara aktif, inovatif, kreatif, efektif, dan menyenangkan sehingga dapat meningkatkan minat dan motivasi belajar peserta didik yang tentunya

Namun kenyataan yang ada belum sepenuhnya sesuai dengan apa yang diharapkan. Minat dan motivasi belajar peserta didik masih ada yang rendah sehingga menyebabkan rendahnya prestasi belajar pula. Hal ini ditunjukkan oleh data

\footnotetext{
${ }^{9}$ Sardiman, Interaksi dan Motivasi Belajar Mengajar, Jakarta: PT Raja Grafindi Persada, 2014, p. 46.

${ }^{10}$ Hamdani, Op.cit., 138

${ }^{11}$ Syaiful Bahri Djamarah,Op.cit., 23
} 
nilai peserta didik kelas A semester VI Program Studi Pendidikan Agama Kristen TahunAjaran 2018/2019 yang berjumlah 14 orang pada prasiklushanya $60 \%$ atau 8 orang yang lulus dengan memperoleh nilai sesuai KKM.

Rendahnya capaian prestasi belajar peserta didik disebabkan oleh beberapa faktor, di antaranya adalah terbatasnya waktu belajar di kelas, fasilitas belajar yang kurang memadai, situasi dan kondisi lingkungan belajar, rendahnya minat dan motivasi belajar peserta didik, serta rendahnya pemahaman tenaga pengajar terhadap penerapan kurikulum dalam proses pembelajaran (curriculum in action). Faktor-faktor tersebut menyebabkan adanya ketidaksesuaian dalam memilih metode pembelajaran yang tepat dalam mencapai suatu kompetensi tertentu.

Penerapan metode konvensional dalam proses pembelajaran seperti ceramah tidak dapat menciptakam proses pembelajarana ktif, innovative, kreatif, efektif dan menyenangkan sehingga menyebabkan sulitnya peserta didik dalam menyerap isi pesan atau materi yang diajarkan, bahkan menyulitkan mereka dalam mengkonstruksikan konsep yang diterima dalam proses pembelajaran tersebut. Metode terdiri dari berbagai

\footnotetext{
${ }^{12}$ Hilda Karli, Implementasi Kurikulum Berbasis Kompetensi; Model-Model Pembelajaran, Bandung: Media Informasi, 2004, p. 6
}

macam, di mana masing-masing memiliki kelebihan dan kekurangan. Pemilihan metode untuk digunakan dalam proses pembelajaran harus disesuaikan dengan karakteristik peserta didik, materi, dan rumusan tujuan yang akan dicapai dalam pembelajaran yang telah ditetapkan.

$$
\text { Hilda Karli }
$$
mengemukakan bahwa rendahnya hasil belajar siswa disebabkan oleh penggunaan metode konvensional secara dominan sehingga peserta didik tidak dapat mengkonstruksikan konsep yang merekapahami dengan baik. ${ }^{12}$

Salah satu metode yang efektif dan efisien yang dapat digunakan dalam pembelajaran di kelas adalah pembelajaran kooperatif dengan teknik jigsaw. Pembelajaran kooperatif dicirikan oleh adanya struktur tugas, tujuan, dan penghargaan kooperatif. Struktur tujuan pada suatu pembelajaran merupakan adanya sejumlah ketergantungan yang diperlukan peserta didik pada saat mereka mengerjakan tugas. Melalui pembelajaran kooperatif para peserta didik didorong, dikehendaki untuk dapat bekerjasama pada suatu tugas bersama, dan mereka harus mengkoordinasikan usahanya untuk menyelesaikan tugasnya. Pembelajaran kooperatif dapat menumbuhkan rasa 
tanggungjawap dari setiap individu didalam kelompok, melatih ketrampilan memimpin untuk mencapai tujuan pembelajaran secara bersama-sama. Pembelajaran kooperatif juga mengacu pada pemberian penghargaan bagi upaya dari setiap peserta didik yang membantu peserta didik lainnya didalam mengerjakan suatu tugas.

Penerapan pembelajaran kooperatif dengan Teknik jigsaw menunjukkan adanya saling ketergantungan diantara dua atau lebih individu untuk mencapai penghargaan bersama. Peserta didik akan dievaluasi atau diberi penghargaan/hadiah yang juga akan dikenakan untuk semua anggota kelompok. Pada dasarnya model pembelajaran kooperatif dengan Teknik jigsaw dikembangkan untuk mencapai tujuan pembelajaran penting, yaitu hasil belajar akademik, penerimaan terhadap keragaman, pengembangan keterampilan sosial, kerja sama dan kolaborasi, serta meningkatkan kinerja peserta didik.

Penerapan pembelajaran kooperatif dengan Teknik jigsaw diasumsikan dapat meningkatkan prestasi belajar peserta didik. Berdasarkan penjelasan tersebut, peneliti tertarik untuk membuat penelitian dengan judul "Meningkatkan Prestasi Belajar Melalui Penggunaan Teknik Jigsaw".

Berdasarkan pada latar belakang di atas, maka perumusan masalah dalam penelitian ini adalah: 1) Apakah penerapan pembelajaran kooperatif dengan teknik jigsaw dapat meningkatkan prestasi belajar peserta didik kelas A semester VI Program Studi Pendidikan Agama Kristen IAKN Manado ?, 2)Apakah penerapan pembelajaran kooperatif dengan teknik jigsaw dapat meningkatkan minat dan motivasi belajar peserta didik kelas A semester VI Program Studi Pendidikan Agama Kristen IAKN Manado?.

Berdasarkan pada masalah penelitian tersebut, maka tujuan dari penelitin ini adalah: 1) Untuk meningkatkan prestasi belajar peserta didik kelas A semester VI Program Studi Pendidikan Agama Kristen IAKN Manado melalui pembelajaran kooperatif dengan teknik jigsaw, 2) Untuk meningkatkan minat dan motivasi belajar peserta didik kelas A semester VI Program Studi Pendidikan Agama Kristen IAKN Manado melalui pembelajaran kooperatif dengan teknik jigsaw

\section{METODE}

Populasi dalam penelitian ini adalah peserta didik semester VI Program Studi Pendidikan Agama Kristen Institut Agama Kristen Negeri Manado Semester Genap Tahun Ajaran 2018/2019, yang berjumlah145 orang. Sampel penelitian diambil dari kelas A semester VI Program Studi Pendidikan Agama Kristen Institut Agama Kristen Negeri Manado Semester GenapTahunAjaran 2018/2019, yang berjumlah 14orang. 
Penelitian ini adalah Penelitian Tindakan Kelas (Classroom Action Research), yang bertujuan untuk memperbaiki kualitas proses pembelajaran di kelas dalam bentuk tindakan refleksi diri yang dilakukan oleh pelaku kegiatan (actor) untuk memperbaiki tingkat rasionalitas dan keadilan tentang praktek Pendidikan, pemahaman, situasi dimana praktek pendidikan tersebut dilakukan (Kunandar, 2008:45-46). ${ }^{13}$

Penelitian ini menggunakan model siklus menurut Kemmis dan Me Taggart, yaitu tindakan dilakukan secara berulangulang dan berkelanjutan (siklus spiral) artinya diharapkan agar semakin diulang tindakannya, akan menghasilkan perubahan hasil belajar yang berarti atau pencapaian prestasi belajar semakin meningkat. Penelitian ini terdiri dari 2 siklus, dengan langkah-langkah sebagai berikut: 1) Perencanaan, 2) Tindakan, 3) Observasi, 4) Refleksi.

Instrumen yang digunakan untuk mengumpulkan data adalah : 1) Hasil post test dari setiap siklus, 2) Evaluasi diri siswa, 3) Hasil observasi selama proses pembelajaran 4) catatan hasil refleksi, 5) Kuesioner. Teknik analisis data dalam penelitian ini adalah: 1) data yang diambil dari hasil tes pada siklus 1 dan 2 untuk

\footnotetext{
${ }^{13}$ Kunandar, Penelitian Tindakan Kelas, Rajawali Pers, 2008, p. 45-46
}

memperoleh nilai pengetahuan, ketrampilan dan sikap dari peserta didik serta prosentase peserta didik yang telah dan belum mencapai nilai sesuai dengan standard kelulusan minimum serta nilai rata-rata, 2) data yang diambil dari kuesioner untuk memperoleh prosentase siswa yang berminat dan tidak dalam penerapan proses pembelajaran kooperatif Teknik Jigsaw dengan langkah-langkah sebagai berikut: 1) mengelompokkan siswa yang berminat dan tidak berminat dalam pembelajaran kooperatif teknik Jigsaw, 2) menghitung prosentase siswa yang berminat dan tidak berminat dalam proses pembelajaran kooperatif dengan Teknik Jigsaw dengan menggunakan rumus:

$$
\text { : } P=\frac{f}{n} \times 100 \% \text {. }
$$

Keterangan:

$P \quad=$ Prosentase jawaban

$\mathrm{f} \quad=$ Frequensi yang menjawab

sn $\quad=$ Banyaknya responden

$100 \%$ = bilangan tetap.

\section{HASIL DAN PEMBAHASAN}

Hasil pembelajaran diambil setelah proses pembelajaran dengan menggunakan kooperatif Teknik Jigsaw selesai dilaksanakan. Dengan skor minimum 60, 
jenis penilaian yang digunakan adalah penilaian kinerja yang dilakukan 2 kali sesudah proses pembelajaran.

\section{Siklus 1.}

Pada awal proses pembelajaran dilakukan brain storming untuk menggali pemahaman peserta didik tentang materi yang akan diajarkan. Respon peserta didik baik karena pertanyaan yang diberikan berkaitan dengan pengalaman mereka. Langkah selanjutnya menjelaskan materi, lalu membentuk 4 kelompok yang masingmasing kelompok terdiri dari 3 dan 4 orang, dan yang akan membagikan kartu materi pada setiap ketua kelompok serta member penjelasan kegiatan yang akan dilakukan. Setiap ketua kelompok bergabung menjadi kelompok inti untuk mendiskusikan materi yang telah diberikan selama 10 menit. Setelah itu mereka kembali ke kelompoknya masing-masing menjadi tutor sebaya mendiskusikan materi tersebut dan membuat rangkuman. Selanjutnya setiap kelompok mempresentasikan hasil diskusinya tapi tutor tidak ikut berdiskusi atau membantu teman kelompoknya. Selanjutnya tutor menjelaskan kembali pada teman kelompoknya hal-hal yang dianggap masih kurang dipahami atau keliru untuk melengkapi hasil presentasi tadi. Kemudian memberikan tugas rumah

Pada pertemuan kedua mengecek tugas rumah peserta didik, masing-masing mencocokkan tugas yang dibuatnya dengan tugas temannya. Membagikan materi baru untuk didiskusikan setiap kelompok. Menunjuk 1 peserta didik yang lain dari setiap kelompok untuk jadi tim inti mendiskusikan materi di tempat terpisah. Tim inti kembali bergabung kekelompoknya dan menjadi tutor sebaya membahas materi sesuai hasil bahasan pada kelompok inti. Tahap berikutnya member 5 soal essay untuk dijawab secara individu. Selanjutnya mencocokkan jawaban dengan jawaban teman. Apabila jawaban berbeda didiskusikan bersama. Memberikan tugas rumah.

Pada pertemuan ketiga, menunjuk peserta didik lain dari setiap kelompok menjadi tim inti, lalu masing-masing mengambil 1 materi yang disiapkan untuk dibahas selama 15 menit di tempat terpisah, sementara teman-teman lainnya membahas secara berpasangan. Selanjutnya tim inti kembali ke kelompoknya masing-masing dan menjelaskan tentang hasil diskusi mereka pada teman-teman kelompoknya sampai mereka mengerti. Selanjutnya kelompok melaporkan hasil diskusi, dan bersama-sama membuat kesimpulan. Selanjutnya melakukan post test ke 1 . Setiap kegiatan di evaluasi secara individu maupun kelompok dan membuat catatan tentang hasil observasi.

\section{Siklus 2}


Pada pertemuan pertama di siklus 2 ini membahas hasil post test 1 dan temuantemuan selama proses pembelajaran bersama peserta didik. Mengundi yang akan jadi anggota tim inti dari setiap kelompok. Tim inti membahas materi baru secara terpisah untuk kemudian jadi tutor sebaya menjelaskan di kelompoknya. Hasil diskusi dari setiap kelompok di share ke kelompok lainnya, jika ada perbedaan dikaji bersama.

Pada pertemuan kedua, setiap kelompok menunjuk 1 orang untuk jadi anggota tim inti yang akan membahas materi baru di tempat terpisah. Semua anggota kelompok mempelajari materi secara individual. Kemudian setiap anggota tim inti bergabung dengan kelompok lain menjadi tutor sebaya di sana. Kelompok yang akan presentasi diundi. Hasil presentasi dari setiap kelompok dilakukan peer correction. Secara klasikal membahas temuan-temuan selama pelaksanaan kegiatan sejak siklus 1 dan membuat kesimpulan.

$$
\text { Pada pertemuan ketiga, }
$$
melaksanakan post test kedua. Skor secara individual diisi pada rubric penilaian. Setiap peserta didik mengisi formulir kuesioner. Mengumumkan kelompok dan anggota tim inti terbaik untuk diberi hadiah/penghargaan. Hasil observasi yang dimuat pada note selama siklus 1 dan 2 yang dilakukan pengajar maupun observer lainnya didiskusikan bersama dan hasil akhir diserahkan kepada tenaga pengajar yang adalah peneliti itu sendiri.

\section{PEMBAHASAN}

\section{a. Siklus 1}

Data hasil penilaian unjuk kerja peserta didik yang berjumlah 14 orang pada siklus 1, nilai terendah adalah 65 , nilai tertinggi 85. Nilai rata-rata pada siklus 1 adalah 75 . Persentase peserta didik yang telah mencapai nilai kelulusan $80 \%$. Mengalami kenaikan dari prasiklus $60 \%$. Terjadi peningkatan 20\%. Hal ini disebabkan karena para peserta didik belum terbiasa dengan teknik jigsaw yang digunakan dalam proses pembelajaran. Minat dan motivasi belajar belum optimal. Data nilai peserta didik pada pra siklus dan siklus 1 dapat dilihat pada tabel berikut :

Tabel 1.

Data Skor Nilai Unjuk Kerjapada

Pra Siklus dan Siklus 1

\begin{tabular}{|c|c|c|c|}
\hline No. & Hasil & Pra Siklus & Siklus 1 \\
\hline 1. & Rata-Rata & 65 & 75 \\
\hline 2. & Nilai Terendah & 50 & 65 \\
\hline
\end{tabular}




\begin{tabular}{|c|c|c|c|}
\hline 3. & Nilai Tertinggi & 80 & 85 \\
\hline 4. & Kategori Bisa (\%) & $60 \%$ & $80 \%$ \\
\hline 5. & Peningkatan hasil (\%) & & $20 \%$ \\
\hline
\end{tabular}

\section{Grafik 1}

Perolehan Nilai Rata-Rata, Peserta Didik yang Memenuhi KKM dan Persentase Peningkatan Hasil Belajar pada Pra Siklus dan Siklus 1

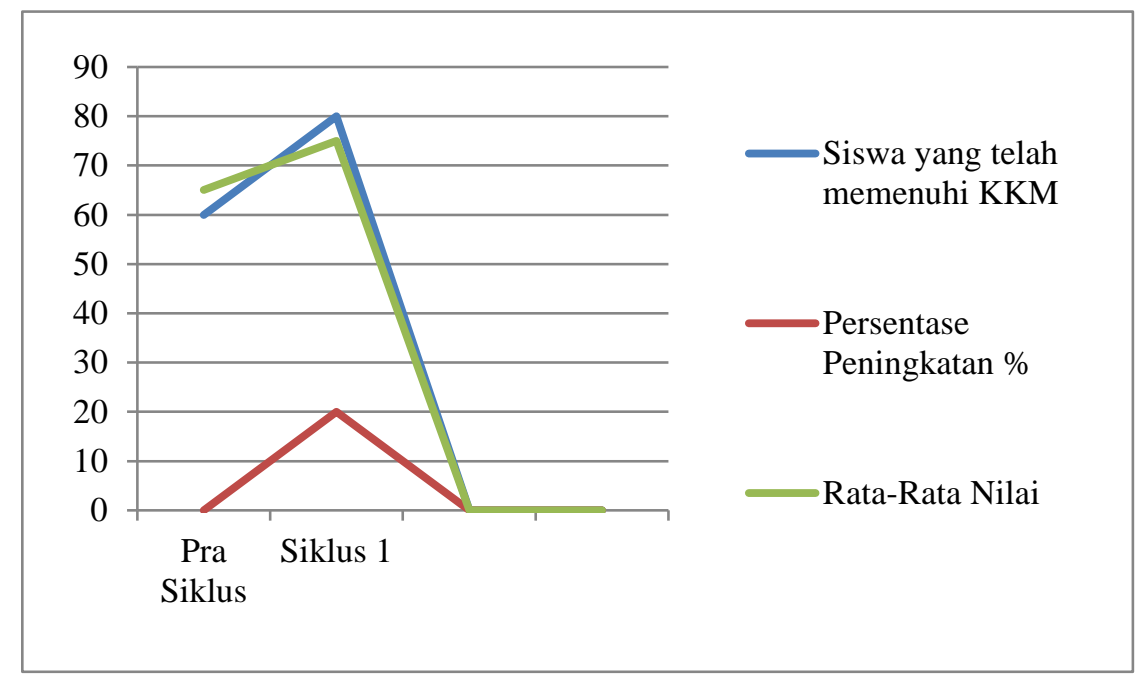

\section{b. Siklus 2}

Pada siklus dua pesertadidikmenjadi antusias dan dapat menikmati pembelajaran. Mereka dengan leluasa dapat mengungkapkan ide-ide didalam kelompok inti dan mentransfernya melalui tutor sebaya dengan menggunakan teknik jigsaw yang dapat memudahkan mereka dalam memahami isi materi yang sedang dipelajari. Data hasil pembelajaran pada siklus 2 mengalami kenaikandibandingkan dengan hasil pada siklus 1, yaitu rata-rata nilai pada siklus 1 adalah 75 menjadi 80 pada siklus 2, nilai terendah 69 , nilai tertinggi 90 dan kategori bisa (telah memenuhi KKM) menjadi $90 \%$. Untuk jelasnya dapat dilihat pada tabelberikut:

Tabel 2.

Data Skor Nilai Unjuk KerjaSiklus 1 dan 2

\begin{tabular}{|c|l|c|c|}
\hline No. & Hasil & Siklus 1 & Siklus 2 \\
\hline 1. & Rata-Rata & 75 & 80 \\
\hline 2. & Nilai Terendah & 65 & 69 \\
\hline 3. & Nilai Tertinggi & 85 & 90 \\
\hline 4. & Kategori Bisa (\%) & $80 \%$ & $90 \%$ \\
\hline 5. & Peningkatan Hasil (\%) & $20 \%$ & $10 \%$ \\
\hline
\end{tabular}

Grafik 2

Perolehan Nilai Rata-Rata, Peserta Didik Memenuhi KKM dan 
Persentase Peningkatan Hasil Belajar Pra Siklus, Siklus 1,Siklus 2

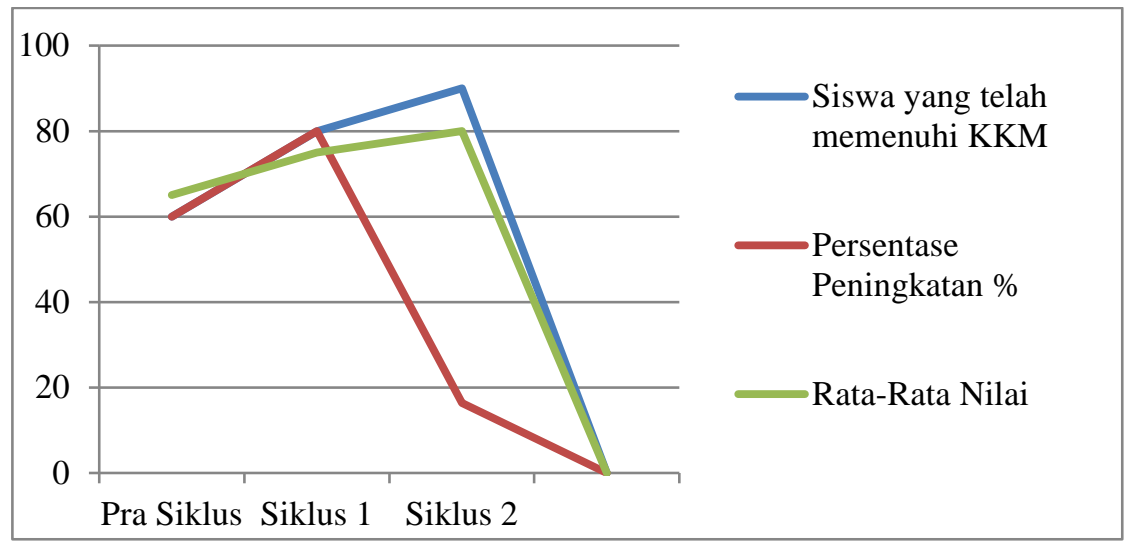

Tabel 1 dan 2, grafik 1 dan 2 didik yang mencapai KKM, dan persentase menunjukkan peningkatan yang signifikan hasil belajar dari siklus 1 sampai siklus 2 . terhadap nilai rata-rata, jumlah peserta

\section{Tabel 3. PersentaseResponPositif danNegative PesertaDidik}

\begin{tabular}{|l|c|c|}
\hline \multicolumn{1}{|c|}{ Siklus } & Reaksi Positif & Reaksi Negatif \\
\hline Siklus 1 & $65 \%$ & $35 \%$ \\
\hline Siklus 2 & $86 \%$ & $14 \%$ \\
\hline
\end{tabular}

Pada table 3, Persentase respon positif terhadap minat dan motivasi belajar peserta didik meningkat secara signifikan, yaitu 65 $\%$ pada siklus 1 menjadi $86 \%$ pada siklus 2.

\section{KESIMPULAN}

Hasil Penelitian Tindakan Kelas dalam pembelajaran kooperatif dengan menggunakan Teknik Jigsaw pada Kelas A semester VI Program studi Pendidikan Agama Kristen Institut Agama Kristen Negeri Manado, dapat disimpulkan sebagai berikut:
1. Pembelajaran kooperatif dengan Teknik Jigsaw dapat meningkatkan prestasi belajar peserta didik.

2. Pembelajaran kooperatif dengan Teknik Jigsaw dapat meningkatkan minat dan motivasi belajar peserta didik.

3. Pembelajaran kooperatif dengan Teknik Jigsaw melatih kerjasama antar individu dalam kelompok untuk mencapai tujuan pembelajaran.

4. Pembelajaran kooperatif dengan Teknik Jigsaw dapat menumbuhkan ketrampilan kepemimpinan. 
Berdasarkan hasil penelitian, maka peneliti menyarankan:

1. Untuk para tenaga pendidik agar dapat mencoba menerapkan pembelajaran kooperatif dengan Teknik Jigsaw untuk meningkatkan prestasi belajar, minat dan motivasi belajar peserta didik.

2. Tenaga pendidik hendaknya melibatkan semua peserta didik secara langsung dalam proses pembelajaran, agar mereka merasa diterima dan dihargai, menumbuhkan percaya diri, keberanian, kerjasama serta melatih ketrampilan memimpin.

\section{DAFTAR PUSTAKA}

Ahmadi, Widodo Supriyono, Psikologi Belajar, Jakarta: Rinek aCipta, 2011.

Arikunto, S. Prosedur Penelitian Suatu Pendekatan Praktek, Jakarta: PT. Rineka Cipta, 2014.

Dharma Kesuma dkk., Pendidikan Karakter Kajian Teori dan Praktik di Sekolah, Bandung: PT Remaja Rosdakarya, 2012

Gagne, M, Robert, Prinsip-Prinsip Belajar Untuk Pengajaran, Surabaya: Usaha Nasional, 1998.

Hamdani, Strategi Belajar Mengajar,

Bandung: Pustaka Setia, 2011.

Hasibuan, J, J, Moedjiono, Proses Belajar Mengajar, Bandung: PT. Remaja Rosdakarya, 1992.
Herudjati Purwok, Penelitian Tindakan Kelas dalam Pengajaran PTK, Jakarta: PT. Indeks, 2010.

Hilda Karli, Implementasi Kurikulum BerbasisKompetensi; Model-Model Pembelajaran, Bandung: Media Informasi, 2004.

Joyce, B., dkk, Models of Teaching (Edisi ke delapan), Yogyakarta: Pustaka Pelajar, 2009.

Kunandar, Penelitian Tindakan Kelas, Rajawali Pers, 2008.

Lulu Winarti, PTK, Seri pendalaman Materi, Esis: Erlangga, 2012.

Me Kay, Sandra Lee, The Reflective Teacher: A Guide to Classroom Research, Singapore: RELC, 2002.

Nana, Sudjana, Cara belajar Siswa Aktif dalam Proses Belajar Megajar, Bandung: Sinar Baru Algensindo, 2010.

Oemar Hamalik, Proses Belajar Mengajar, Jakarta: Bumi Aksara, 2005.

Rismayanti, Anita, The Effectiveness of Brainstorming Technique in Improving Studens' Speaking Skill, Bandung. (Paper).

Riyanto, Y, Metodologi Penelitian Pendidikan, Surabaya: SIC., 2001.

Rooijakkers, Ad.,Mengajar Dengan Sukses, Jakarta: Gramedia, 2008.

Ruswandi, Muhammad, Games for Islamic Mentoring, Bandung: Syaamil Cipta Media, 2004. 
Sardiman, Interaksi dan Motivasi Belajar Mengajar, Jakarta: PT Raja GrafindiPersada, 2014.

Slameto, Belajar dan Faktor-Faktor yang Mempengaruh Proses Belajar, Jakarta: PT Rineka Cipta, 2018.

Soedijarto, Media Pembelajaran, Modul PLPG, Surakarta: 2008.

Syaiful Bahri Djamarah, Prestasi Belajar Dan Kompetensi Guru. Surabaya: Usaha Nasional, 2012.
Tarigan, H.G, Pengajaran PTK. Jakarta:

Departemen Pendidikan dan Kebudayaan, 1989.

Tilaar, Paradigma Baru Pendidikan Nasional, Jakarta: Rineka Cipta, 1990.

Trianto, Model-Model Pembelajaran Inovative. Jakarta: Prestasi Pustaka Abu. 2007.

Usman, A, Dan Setiawati, S, Pengoptimalan Kelas, Jakarta: Departemen Pendidikan dan Kebudayaan 1993. 